\title{
Teacher Education and the Targeting of Disadvantage
}

\author{
Bruce Burnett, Jo Lampert \\ School of Cultural and Language Studies, Queensland University of Technology, \\ Brisbane, Australia. \\ Email: b.burnett@qut.edu.au, j.lampert@qut.edu.au \\ Received October 24 $4^{\text {th }}$, 2011; revised November 23 ${ }^{\text {rd }}, 2011$; accepted December $5^{\text {th }}, 2011$.
}

\begin{abstract}
This paper outlines the Exceptional Teachers for Disadvantaged Schools (ETDS) project which began in June 2010 with the aim of developing and documenting an Australian university-based teacher education program specifically focusing on the preparation of high quality teachers for the disadvantaged school sector. ETDS constitutes a novel model of teacher education targeting disadvantaged schooling in that the selection of participating pre-service teachers has been based on their proven academic performance over the first 2 years of their 4-year Bachelor of Education degree. ETDS has established a modified curriculum that better supports the on-campus training of this cohort while also targeting the role of field experience within partner disadvantaged school settings. This paper offers a rationale for the model, unpacks its various phases and provides a justification of the model's selection criteria based on high academic achievement.
\end{abstract}

Keywords: Teacher Education, Teacher Quality, Disadvantaged Schools

\section{Introduction}

Concerns about educational disadvantage have taken centre stage in recent years, with renewed attention on the relationship between quality teaching and social and economic participation. While OECD member countries have focused on the links between poverty and educational outcomes, since 2008 there has been a discernible change in the Australian government's emphasis toward the promotion of Social Inclusion. While in terms of education this broad agenda has clearly influenced several domains of policy in Australia, its impact is most easily observed in the considerable allocation of funding targeting low socio-economic status participation (i.e. Higher Education Participation and Partnership Program-HEPPP) and targeted educational reform via the National Partnership Agreements (i.e. Teacher Quality and Low SES School Communities). In Australia this offers new and exciting opportunities for reform to eligible schools.

Inherent in this redistribution of resources is an explicit rationale that links levels of socio-economic disadvantage with a student's educational success, participation and performance. While educational researchers have long highlighted broad equity disparities in educational outcomes and attempted to explain differential effects on dissimilar groups of students (Bernstein, 1996, Bourdieu, 1991; Connell, White, \& Johnson, 1991), various initiatives have explored the underlying reasons for this gap, including quality teachers, teacher education, and issues related to social justice. For instance, a distinct tangent of literature has begun to critique the degree to which homogeneous teaching populations are ill prepared to engage with increasingly heterogeneous populations of students (Cochran-Smith \& Fries, 2005). Sleeter (2008) writes about the lack of awareness middle-class teachers have of students who come from cultural and socioeconomic backgrounds different from their own and with which they may be unfamiliar and ill prepared to teach.

There are frequent calls for more explicit research focusing on teacher education programs that better prepare high-quality teachers who are specifically educated to work in disadvan- taged schools (HOWARD \& ALEMAN, 2008; Rice, 2008). Rice (2008: p. 1) argues for a need to place more of the "very best teachers into the most challenging schools", yet the problem is not merely one of training more teachers, for disadvantaged schools already receive disproportionate numbers of beginning teachers (Connell, 1994; Vickers \& Ferfolja, 2006). Rather, the crisis is one that Grossman and Loeb (2010: p. 245) argue centers on the common practice of "[p]lacing the least experienced teachers with the most needy students”.

The lack of quality teachers for low socioeconomic schools is of international concern with Rotberg (2004: p. 363) defining the problem as a mandate to get "highly qualified teachers" in every classroom serving at-risk children and reasonably defining what such teachers need. The potential social, economic and educational benefits of placing high-quality teachers in disadvantaged school settings is highlighted by a wide range of research that stresses the positive influence of good teachers on academic performance. Current research suggests that good teaching outweighs other variables such as class size or composition (Darling-Hammond, 2006; Hanushek, Kain, \& Rivkin, 2004; Sanders \& Horn, 1994; Sanders \& Rivers, 1996). Hattie (2003) maintains that teachers account for about 30 percent of variance in student achievement, while Darling-Hammond (2006) suggests that students who have highly effective teachers for three consecutive years score as much as 50 percentile points higher on achievement tests than those who have ineffective teachers for the same amount of time. Recent research into teacher effectiveness demonstrates that the performance gap between the best teachers and the worst teachers is far greater than commonly supposed with the work of Berliner (1992) for example, highlighting the importance of pedagogical expertise and how such knowledge and skills are complex and domain-specific.

\section{Addressing Educational Disadvantage}

The terms disadvantaged (Connell, 1994; Darling-Hammond, 2010; Ferfolja, 2008), hard-to-staff (Castro et al., 2010; Darling-Hammond, 2010) or at-risk schools (Castro et al., 2010; Darling-Hammond, 2010; Ferfolja, 2008; Ladson-Billings, 2008) 
are often used interchangeably. The Exceptional Teachers for Disadvantaged Schools project (ETDS) has favoured the term disadvantage in line with current language used in Australian educational institutions combined with the explicit links between the low socio-economic status and poor educational outcomes of the communities which these schools service.

The Exceptional Teachers for Disadvantaged Schools project is clearly not the first attempt to address the need for quality teachers in disadvantaged schools. Rather, it builds on previous work both in Australia and internationally. For instance, the Australian Disadvantaged Schools project (Connell, 1991) provided one of the first "compensatory" models of teaching for disadvantage and was established across Australia in 1974 in order to specifically address the educational disadvantages experienced by students from low socio-economic backgrounds. While disparities in educational outcomes in relation to disadvantage have remained a consistent theme over the past decades, much of the most influential research has examined disadvantage from discrete standpoints. Such perspectives include an emphasis on literacy/numeracy (Comber, \& Kamler, 2004; Freebody, 1992; Luke, 2004), pedagogy/professional development (Hayes et al. 2006; Timperley \& Alton-Lee, 2008) and location/place (Gannon, 2009; Somerville, 2006; Thompson, 2003). In Australia teacher education institutions such as the University of Western Sydney currently provide an innovative model of teacher education that links pre-service teachers with schools that have high refugee populations (Ferfolja, 2008), while La Trobe University's Bachelor of Outreach and Community Education combines a focus on student welfare together with a teacher education component that meets the requirements of secondary school teaching registration in Victoria. The ETDS project is at present however, the only mainstream Australian teacher education model that specifically targets sizeable cohorts of academically high achieving pre-service teachers with the overt aim of channelling graduates of the program into disadvantaged schools.

Research outside the Australasian context, from both North America and the UK point to the challenges of recruiting, staffing and retaining quality teachers in disadvantaged schools (Donaldson \& Johnson, 2010). In the United States, this is evident in major reforms seeking to address the difficulties of attracting high quality teachers to "high poverty schools" (Quartz et al., 2008). Research from the United States has focused on the dearth of quality teachers for the "neediest" of children and youth and highlight issues such as novice teachers' ineffective teaching practices, "burn-out" and most significantly their lack of preparedness (McCarthy \& Guiney, 2004). In Britain, the crisis is also well documented, with clear evidence that inexperienced teachers are actively recruited and channelled into areas of greatest need (Adams \& Tulasiewicz, 2005). In Canada, similar concerns about teacher education highlight links between poverty and the achievement gap and the urgent need for quality research in the area (Levin, 2010). More specifically, Canadian research highlights the degree to which disadvantage within urban and rural and remote schools/setngs is contextual and differs from location to location (McDougall, Gaskell, \& Flessa, 2006).

One solution to the shortage of quality teachers in disadvantaged schools has been offered by Teach for America (TFA), which operates as part of America's National Community Service or AmeriCorps. TFA recruits recent college graduates and professionals and after 5 weeks of intensive training, places them in low-income community teaching positions for two years. The TFA model has expanded to seven international regions including Australia, and while the immediacy inherent in the model is appealing to some, TFA remains the focus of considerable debate within the profession in terms of both the quality of training and the retention of graduates (see for example Logan, \& Binnie, 2010; Darling-Hammond, 2005, 2006, 2010). The perception that public school teachers fail to meet the needs of disadvantaged children has been highlighted in the popular US documentary film Waiting for Superman (2010). While the film has been both lauded and highly criticised for its anti-union stance and the call for (private) charter schools (Ravitch, 2011), the popular sense that better teachers are needed for the children most at risk is now firmly part of a very public discourse, one constantly reinforced by Hollywood's glorified portrayal of the heroic inner-city teacher as saviour.

\section{The Exceptional Teachers for Disadvantaged Schools Project}

The ETDS project set out to develop, implement and monitor a customised model of teacher education that responded to a range of recent demands for quality education in low SES and disadvantaged schools. Critically, the project moved the focal point of teacher education for disadvantaged schools from the "missionary" (Larabee, 2010) or deficit (Comber \& Kamler 2004; Flessa, 2007) approaches of the recent past, towards a position that explicitly centred on notions of academic excellence ${ }^{1}$. Underpinning the design of the project was the clear goal of equipping cohorts of high-quality pre-service teachers with new sets of skills and understandings of disadvantage and ultimately, encouraging them to select employment in schools where they could make a real difference.

It was initially envisaged that the ETDS model would contain three distinct stages. First, it would identify the highest achieving undergraduates studying to be teachers. Second, it would provide this cohort with a modified curriculum that allowed a much more sophisticated understanding of poverty and curriculum and pedagogical research associated with educational disadvantage, and third, it would provide exposure for these exceptional pre-service teachers to key disadvantaged urban, regional and remote school settings for their 3rd and 4th year practicum or field placements. A fourth stage has been added to the project and will commence in 2012 with the longitudinal tracking of ETDS participants after they graduate to ascertain employment destinations, retention data and performance.

Despite there being little in the literature that suggests it is possible to define, select or ascertain "good teachers" for disadvantaged schools solely by looking at "attributes" or personality type (Hattie, 2004) the idea that personal attributes to a large degree predetermine a teacher's success in a disadvantaged school is a commonly voiced sentiment. However as Kennedy (2010) reminds us, it is tempting to succumb to the notion that 'personal qualities' are the only things that matter for good teachers. Instead, the ETDS project looks beyond attributes, believing content knowledge, situational influences, contextualised and well-theorised understandings, extensive mentoring and specialised curriculum and pedagogy are significant factors in producing great teachers. In the growing body of knowledge on quality teaching, it would appear that "good intent" and personal characteristics are not enough. Ex-

${ }^{1}$ Principals of our participating schools repeatedly ask us not to send them anyone who "thinks they can save the world". 
pert teachers need to be well educated, well mentored and well prepared, especially if they are to stay for any length of time in challenging schools.

While acknowledging the large body of literature focusing on the attributes of good teachers and teaching (Feiman-Nemser, 2001; Ferfolja, 2008; Hattie, 2003), an essential component of the ETDS project is the notion that the cohort must begin with high pre-existing levels of content knowledge. For this reason high academic achievement is the most important initial criterion for identification of the ETDS cohort. Hence, there is an assumption that the participants come with strong content knowledge and are already be equipped with the core English, Mathematics, Science or other disciplinary skill sets that are taken as a "given" in excellent teachers. Thus the ETDS program is freed from the outset to focus on a modified curriculum and targeted practicum exposure.

In addition to the operational side of the ETDS project, the research component focuses on the following questions:

1) What knowledge, skills and dispositions [in addition to academic excellence] help identify high-quality novice teachers for disadvantaged schools?

2) How can the knowledge, skills and dispositions of highquality pre-service teachers be enhanced and facilitated through a modified teacher education curriculum targeting disadvantaged school settings?
3) How can the partnership between university-based teacher education and targeted school-based field experience within disadvantaged schools be improved?

\section{Phases of ETDS}

The ETDS model consists of four stages. Data is collected in each stage and provide a mechanism or "feedback loop" where the research team learns what works (and does not work) for preparing teachers to work in disadvantaged settings, and importantly allows for both the research and the model to be adjusted. This process is outlined in Figure 1.

\section{Phase 1: Identification of Cohort}

ETDS participants are involved in the project during their 3rd and 4th years (the last two years of their degree). Each year a new cohort of approximately thirty (30) 3rd year Bachelor of Education (Primary/Elementary and Secondary/High School) pre-service teachers are identified, interviewed and selected from the total BEd cohort. While the first iteration of ETDS in 2010 used the students' GPA or academic achievement as a selection criterion, the project also seeks to ascertain what attributes and dispositions (additional to academic excellence) help identify selection. Ensuing cycles will therefore examine further aspects such as the students' prior experience with disadvantaged communities or their understanding of the cultural

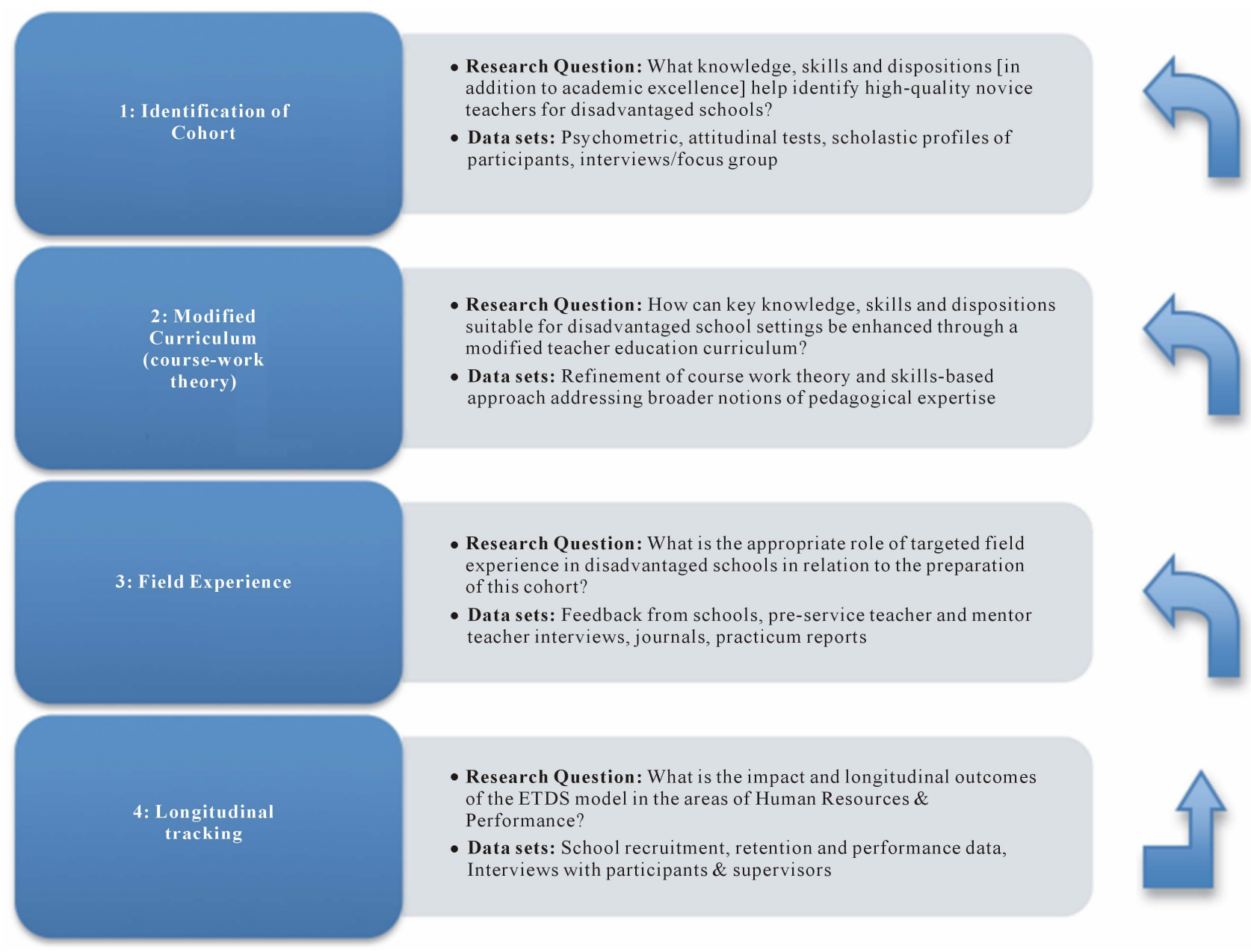

Figure 1.

Exceptional teachers for disadvantaged schools (phases and feedback loop). 
and socio-economic factors that impact student educational outcomes.

Unlike research that targets qualities such as "sense of mission” (Nieto, 2005) as a prerequisite for teachers working in disadvantaged settings, ETDS begins primarily with academic achievement, believing a commitment to social justice is not necessarily a prerequisite but rather something that can grow and be enhanced through;

- Engagement with a modified curriculum.

- Positive and reflected experiences on practicum and or with mentor teachers, and

- Through concentrated engagement with selected theory related to understanding poverty, the dynamics of disadvantage and pragmatic forms of social justice.

Researching the experiences of the first cohort we hope our teacher education program can respond to what some of our participating Principals have identified as the proliferation of "missionary teachers" in their schools. In line with current thought on teacher quality, the ETDS program aims to prepare teachers to do more than merely provide a caring, supportive environment for students; it aims as well to provide schools with teachers who can offer academic excellence in their content areas.

Phase 2: Modified Curriculum (i.e. Course-Work Theory)

In their 3rd year, and as part of their normal course progression, participants undertake a socio-cultural foundation unit where they participate as a separate cohort with a specific focus on disadvantage and schooling. Where possible and appropriate the content has been adapted to focus on a theory-based understanding of poverty and the dynamics of the low SES schooling sector (Connell, 1994; Darling-Hammond, 2005; Flessa, 2007). Students are presented with topics ranging from the identification of disadvantage via various Australian Government indexes to skill-based focused discussions of behaviour/classroom management strategies. On these topics, and others that arise from year to year, students become familiar with current practices and policy and regularly engage in informed critique of current discourses around topics related to disadvantage and education. Importantly the cohort remains together whilst participating in a foundation unit that is part of the students' BEd core coursework, and thus does not place additional demands, nor impact on faculty resourcing. Additional workshops and advanced seminars are provided to the cohort during their fourth year by the state education department-Education Queensland. In 2011, this took the form of the state department funding full participation at their Smarter-Schools National Partnerships Schools Teacher Induction Conference 2011 where the ETDS pre-service teachers participated (along with approximately 200 principals and teachers working in Queensland disadvantaged schools) in a 2-day professional development program. In addition, and in response to cohort feedback, participating school principals and teachers are regularly invited on campus to lead the focused skill-based discussions on behaviour management, thus contributing the program's crucial partnership between teacher training and school-based practice.

\section{Phase 3: Field Experience (i.e. Practicum)}

ETDS participants are involved in a normal course progression in terms of their practicum, however each occurs in a selected/partner disadvantaged school site. ETDS participants undertake a total of $3 \times 20$-day field placements (in addition to a final 20-day Internship) in IRSED (Index of Relative Socioeconomic Disadvantage) identified school locations across urban, regional or remote locations. Each student is allocated an experienced participating mentor or supervising teacher over the course of his or her practicum experience (identified by their school Principal as experienced, exceptional or "expert"). While the first iteration of ETDS in 2010 established relationships with 10 IRSED identified schools, each subsequent cycle will identify additional locations and numerous schools asking to participate have now approached us. Where possible, participating school sites accept a cluster of 4 ETDS pre-service teachers. This has proved advantageous both in terms of how the pre-service teachers are able to support each other and the logistical benefits inherent in a smaller manageable number of practicum locations.

\section{Phase 4: Longitudinal Tracking}

The final component of ETDS will begin in 2012 longitudinally tracking graduating participants to determine the impact and implications of the ETDS model on 1) teacher recruitment (particularly in relation to the success of the project in channelling graduating ETDS participants into disadvantaged schools); 2) teacher retention (in terms of both ETDS graduates, and of novice teachers more generally appointed to disadvantaged schools, and 3) teacher performance. Over 5 years the ETDS project will have graduated approximately 150 teachers with distinct training in low SES school settings, other outcomes consist of new insights related to the attributes of quality teachers for disadvantaged schools; the development of an evidence based model for teacher education that draws on and expands current practice and theory in relation to disadvantaged schooling, and evidence of the impact and longitudinal effects of the ETDS model.

\section{Concluding Comments}

The ETDS project began in May 2010, by identifying 28 students from a total cohort of approximately 600 Bachelor of Education pre-service teachers. Initial selection was made on the basis of the students' outstanding Grade Point Average (GPA) or academic achievement over the first and second years of their 4-year Bachelor of Education degree, with special attention paid to their performance in two foundational sociocultural units, a demonstrated commitment to the project's objectives and requirements of the trial. While each of the students was initially identified by GPA, each was also interviewed and a subsequent half-day briefing/workshop was conducted where the participants met for the first time as a group and much greater detail of the model was provided along with an explanation of the research component of the project. It was made clear to the group that there was no compulsion for any student to participate and it was stressed that they would not be required to undertake a significant additional study load. A critical component of the model was that it must operate as part of a student's normal course progression. In other words, ETDS participants would be required to study the same subjects/units and would undertake the usual number of prescribed Field Study days in schools, however what set the group apart was that they would participate as a distinct cohort with an explicit focus on issues related to disadvantage and poverty. From the 28 students who attended the briefing, only two chose not to participate in the program; one due to the travelling distance required to take part in the project (as they were attending a regional campus), and another who wished to pursue a career teaching within a particular faith-based educational organisation. In 2011 the second cohort of ETDS undergraduates were invited to participate. This new group of 30 pre-service teachers are in the first stages of the program while the first group are 
now on their final practicum placement. With each new cohort we add to our knowledge of what works, what the schools want from graduates, where we may have gaps in our existing program and what we can do to support participants to become the best teachers for the schools that need them most.

As the project commenced we knew that academic achievement would not be the only thing that mattered in the success of the ETDS cohort. Though academic excellence was our starting point and a non-negotiable, the first year of the project has identified several other variables of significance in determining how suitable individual members of the cohort are to teaching in a disadvantaged school, in particular whether they continued with the project and how well they did on their ETDS practicum. Though, as confirmed by previous research (e.g. Hattie, 2004) we have found little evidence yet that there are particular 'personality traits' that are desirable for teachers working in disadvantaged schools, we are increasing our understanding of the importance of such factors as 1) a passion for working in the area of disadvantage; 2 ) their own backgrounds or experience either coming from or having previously worked in disadvantaged communities; 3) their strong commitment to gaining employment in disadvantaged schools. These factors will now be taken into account in the selection of each ETDS cohort.

While analysis of the data over a longer period is required, an initial reading suggests that the project has been positively received by the participating schools, by the pre-service ETDS cohort, and by the local employing authority-Education Queensland who are watching the project with keen interest. While the success of ETDS may be partly due to the process of selecting an elite group of academic high achievers, it may also have been significantly influenced by what some within the group described as "filling a hole" previously missing in their undergraduate studies and the sense, expressed by one mature age member as "finally doing something worthwhile with my life".

As the ETDS project enters its second year we gain knowledge of the complex and at times conflicting discourses around the preparation of pre-service teachers for some of the most difficult teaching environments: disadvantaged school classrooms. Clearly the most prominent theme to emerge revolves around how to strike the correct balance between teacher knowledge, disposition and skills. It is anticipated that the project's success in building teacher capacity will remain contingent on the delicate and evolving relationship between selection of the cohort, the on-campus theory driven component of the program and the crucial scaffolded exposure to the field during practicum. It is envisaged that over the next four years the ETDS project will continue to provide a productive foundation for research and professional training for the disadvantaged schooling sector. ETDS is a teacher education program investing in new quality teachers for disadvantaged schools. It is hoped that the initial learnings outlined in this paper can contribute to discussion on how high quality teachers are to be identified, encouraged and prepared to take up careers in disadvantaged schools.

\section{References}

Adams, A., \& Tulasiewicz, W. (1995). The crisis in teacher education: A European concern? London: Falmer Press.

Berliner, D. C. (1992). Telling the stories of educational psychology. Educational Psychologist, 27, 143-161. doi:10.1207/s15326985ep2702_2

Bernstein, B. (1996). Pedagogy, symbolic control and identity: Theory, research, critique. London: Taylor and Francis.
Bourdieu, P. (1991). Language and symbolic power. Cambridge: Polity Press.

Castro, A. J., Kelly, J., \& Shih, M. (2010). Resilience strategies for new teachers in high needs areas. Teaching and Teacher Education, 26, 622-629. doi:10.1016/j.tate.2009.09.010

Cochran-Smith, M., \& Fries, K. (2005). Researching teacher education in changing times: Politics and paradigms. In M. Cochran-Smith, \& K. Zeichner (Eds.), Studying teacher education: The report of the AERA panel on research and teacher education (pp. 69-107). Washington, DC: American Educational Research Association.

Comber, B., \& Kamler, B. (2004). Turn-around pedagogies: Improving the education of at-risk students. Improving Schools, 8, 121-131.

Connell, R. W. (1994). Poverty and education. Harvard Educational Review, 64, 125-150.

Connell, R. W., White, V. M., \& Johnston, K. M. (1991). Running twice as hard: The disadvantaged schools program in Australia. Burwood: Deakin University Press.

Darling-Hammond, L. (2006). Powerful teacher education: Lessons from exemplary programs. San Franciso: Jossey-Bass.

Darling-Hammond, L. (2010). Teacher education and the American future. Journal of Teacher Education, 61, 35-47. doi:10.1177/0022487109348024

Donaldson, M, L., Moore, J. S. (2010) The price of misassignment: The role of teaching assignments in teach for America teachers' exit from low-income schools and the teaching profession. Educational Evaluation and Policy Analysis, 32, 299-323. doi:10.3102/0162373710367680

Feiman-Nemser, S. (2001). Helping novices learn to teach: Lessons from an exemplary support teacher. Journal of Teacher Education, 52, 17-30. doi:10.1177/0022487101052001003

Ferfolja, T. (2008). Building teacher capital in pre-service teachers: Reflections on a new teacher-education initiative. Australian Journal of Teacher Education, 33, 68-84.

Flessa, J. J. (2007). Poverty and education: Towards effective action. Toronto: Elementary Teachers' Federation of Ontario.

Freebody, P. (1992). A socio-cultural approach: Resourcing four roles as a literacy learner. In A. Watson, \& A. Badenhop (Eds.), Prevention of reading failure (pp. 48-60). Sydney: Ashton-Scholastic.

Gannon, S. (2009). Rewriting "the road to nowhere": Place pedagogies in western Sydney. Urban Education, 44, 608-624. doi:10.1177/0042085909339377

Grossman, P., \& Loeb, S. (2010). Learning from multiple routes. Educational Leadership, 67, 22-27.

Hanushek, E. A., Kain, J. F., \& Rivkin, S. G. (2004). Why public schools lose teachers. The Journal of Human Resources, 39, 326-354. doi:10.2307/3559017

Hattie, J. (2003). Teachers make a difference: What is the research evidence? ACER Annual Conference, Melbourne, 7-11 July 2003.

Hattie, J. (2004). It's official: Teachers make a difference. Educare News: The National Newspaper for All Non-Government Schools, 144, 24-31,

Hayes, D., Mills, M., Christie, P., \& Lingard, B. (2006). Teachers and schooling making a difference: Productive Pedagogies, assessment and performance. Crows Nest: Allen \& Unwin.

Howard, T. C., \& Aleman, G. R. (2008). Teacher capacity for diverse learners: What do teachers need to know? In M. Cochran-Smith, S. Feiman-Nemser, \& D. J. McIntyre (Eds.), Handbook of research on teacher education: Enduring questions in changing contexts. New York: Routledge, Taylor \& Francis Group.

Kennedy, M. (2010). Attribution error and the quest for teacher quality. Educational Researcher, 39, 591-598. doi:10.3102/0013189X10390804

Ladson-Billings, G. (2008). A letter to our next president. Journal of Teacher Education, 59, 235-239. doi:10.1177/0022487108317466

Levin, B. (2010). How to change 5000 schools: A practical and positive approach for leading change at every level. Cambridge: Harvard Education Press.

Logan, C., \& Binnie, K. (2010). Union rejects "flawed” teacher training plan. ABC News, 22 February 2010.

Luke, A. (2004). Australia: The challenges of poverty, pedagogy and pathways. In I. C. Rotberg (Ed.), Balancing change and tradition in global education reform. Lanham, MD: Scarecrow Education.

McCarthy, M., \& Guiney, E. (2004). Building a professional teaching 
corps in Boston: Baseline study of new teachers in Boston's public schools. Boston: Boston Plan for Excellence.

McDougall, D., Gaskell, J., Flessa, J. J., Kugler, J., \& Jang, E. E. (2006). Improving student achievement in schools facing challenging circumstances. Toronto: University of Toronto.

Nieto, S. (2005). Why we teach. New York: Teachers College Press.

Quartz, K, H., Thomas, A. \& Anderson, L. (2008) Careers in motion: A Longitudinal retention study of role changing among early-career urban educators. Teachers College Record, 110, 218-250.

Ravitch, D. (2010). The myth of charter schools. The New York Review of Books.

http://www.nybooks.com/articles/archives/2010/nov/11/myth-charter -schools/?pagination=false

Rice, S. (2008). Getting good teachers into challenging schools. Curriculum Leadership, 6, 1-3.

Rotberg, I. C. (2004). Balancing change and tradition in global education reform. Lanham, MD: Scarecrow Education.

Sanders, W. L., \& Horn, S. P. (1994). The Tennessee value-added assessment system (TVAAS): Mixed-model methodology in educational assessment. Journal of Personnel Evaluation in Education, 8,
299-311. doi:10.1007/BF00973726

Sanders, W. L., \& J. C., Rivers. (1996). Cumulative and residual effects of teachers on future academic achievement. Knoxville: University of Tennessee Value Added Research and Assessment Centre.

Sleeter, C. (2008). Preparing white teachers for diverse students. In M. Cochran-Smith, S. Feiman-Nemser, \& D. J. McIntyre (Eds.), Handbook of research on teacher education: Enduring questions in changing contexts. New York: Routledge, Taylor \& Francis Group.

Somerville, M. (2006). An enabling place pedagogy for new teachers. Annual AARE Conference, University of South Australia, Adelaide, 8-9 November 2006.

Timperley, H., \& Alton-Lee, A. (2008). Reframing teacher professional learning: An alternative policy approach to strengthening valued outcomes for diverse learners. Review of Research in Education, 32, 328-369. doi:10.3102/0091732X07308968

Vickers, M., \& Ferfolja, T. (2006). The classmates education initiative. Curriculum Leadership, 4.

http://www.curriculum.edu.au/leader/the_classmates_teacher_educati on_initiative_at_uws,15816.html?issueID $=10414$ 